\title{
Renin-angiotensin system inhibitor attenuates oxidative stress induced human coronary artery endothelial cell dysfunction via the PI3K/AKT/mTOR pathway
}

\author{
Xuekun Shi ${ }^{1}$, Yuhua Guan², Shaoyan Jiang ${ }^{1}$, Tiandong Li ${ }^{1}$, Bing Sun ${ }^{1}$, Huan Cheng ${ }^{2}$
}

\author{
${ }^{1}$ Department of Cardiovasology, the Affiliated Cardiovascular Hospital of Qindao \\ University, Qindao, Shaodong, China \\ ${ }^{2}$ Department of Neurology, the BaZhou People's Hospital of Xinjiang Uygur \\ Autonomous Region, XinJiang Uygur Autonomous Region, China
}

Submitted: 12 December 2017

Accepted: 15 January 2018

Arch Med Sci 2019; 15, 1: 152-164

DOI: https://doi.org/10.5114/aoms.2018.74026

Copyright @ 2018 Termedia \& Banach

\section{Abstract}

Introduction: The renin-angiotensin system is associated with blood pressure regulation, inflammation, oxidative stress and insulin resistance. It can decrease intracellular oxidative stress. Stimulation with $\mathrm{H}_{2} \mathrm{O}_{2}$ leads to increased oxidative stress and activation of the AKT/mTOR pathway. However, the role of renin-angiotensin system inhibitors in oxidative stress-induced endothelial cell dysfunction and $\mathrm{H}_{2} \mathrm{O}_{2}$-induced AKT activation remains unclear.

Material and methods: Human coronary artery endothelial cells (HCAECs) were used. The cells were treated with $\mathrm{H}_{2} \mathrm{O}_{2}$, captopril, the AKT inhibitor MK2206, and the AKT activator SC79, either separately, or in combination. p53 and ICAM-1 expression, and p-eNOS, p-Akt and mTOR activation were measured by Western blot. Cell viability was assessed by MTT assay. Levels of reactive oxygen species (ROS) were assayed by flow cytometry. Proliferation was monitored by BrdU labeling, while cell migration and invasion were determined by wound healing and Transwell assays, respectively.

Results: The renin-angiotensin system inhibitor captopril reversed $\mathrm{H}_{2} \mathrm{O}_{2}$-induced oxidative stress and apoptosis in HCAECs. Co-treatment with captopril and the AKT inhibitor MK-2206 reduced the $\mathrm{H}_{2} \mathrm{O}_{2}$-induced P53 and ICAM-1 protein expression $(p<0.05)$. The proliferation, migration and invasion of HCAECs were significantly enhanced by co-treatment with captopril and MK$2206(p<0.05)$.

Conclusions: The study revealed the protective effect of captopril against $\mathrm{H}_{2} \mathrm{O}_{2}$-induced endothelial cell dysfunction through the AKT/mTOR pathway, and its enhancement of cell survival. These findings provide new insights into the protective effects of captopril and novel therapeutic approaches to treatment of cardiovascular disease.

Key words: renin-angiotensin system inhibitor, AKT/mTOR pathway, oxidative stress, apoptosis, endothelial cell dysfunction.

\section{Introduction}

Endothelial dysfunction is an early feature of atherosclerosis and cardiovascular disease $[1,2]$. The protection of endothelial function can prevent the development of cardiovascular disease [3,4]. Endothelial dys-

\author{
Corresponding author: \\ Yuhua Guan \\ Department of Neurology \\ the BaZhou People's \\ Hospital of Xinjiang \\ Uygur Autonomous Region \\ XinJiang Uygur \\ Autonomous Region \\ 841000, China \\ E-mail: Yukwahguan@163.com
}


function leads to several pathological conditions such as impairment of the anti-inflammatory properties of the endothelium, impaired modulation of vascular growth, and dysregulation of vascular remodeling [5]. Early studies have demonstrated that endothelial dysfunction is caused by decreases in nitric oxide (NO) bioactivity in the vessel wall [6]. Endothelial nitric oxide synthase (eNOS) catalyzes the generation of NO in endothelial cells. It is a paracrine factor that controls vascular tone [7]. Increases in reactive oxygen species (ROS) production can reduce the bioavailability of NO from endothelial cells, leading to endothelial dysfunction and the initiation and development of cardiac disease $[8,9]$.

The nicotinamide adenine dinucleotide phosphate oxidase (NADPH oxidase) system is the main cellular source of ROS in endothelial cells [10]. Reactive oxygen species play fundamental roles in various signaling pathways under normal physiological conditions [11]. They are produced by various oxidase enzymes, including NADPH oxidase and uncoupled eNOS [12]. The antioxidant enzyme superoxide dismutase (SOD) rapidly dismutates the superoxide anion $\mathrm{O}_{2}^{-}$to hydrogen peroxide $\left(\mathrm{H}_{2} \mathrm{O}_{2}\right)$. Intracellular concentrations of ROS are regulated by several signaling pathways through interaction with the intracellular antioxidant system. Impairment of this antioxidant system leads to sustainable ROS exposure in cells. These intracellular ROS include superoxide and $\mathrm{H}_{2} \mathrm{O}_{2} \cdot \mathrm{H}_{2} \mathrm{O}_{2}$ has high chemical stability at steady state concentration [13]. Many cell types produce $\mathrm{H}_{2} \mathrm{O}_{2}$ in response to growth factors and insulin, which promote cell proliferation, differentiation, and migration [14]. It has been suggested that $\mathrm{H}_{2} \mathrm{O}_{2}$ promotes the functions of various proteins such as protein phosphatases, protein kinases and transcription factors [15]. Stimulation with $\mathrm{H}_{2} \mathrm{O}_{2}$ initiates downstream signaling events, such as mitogen-activated protein kinases (MAPK) and activation of the mammalian target of rapamycin (mTOR) pathway. Interestingly, AKT regulates downstream substrates that mediate apoptosis and plays a crucial role in the regulation of cellular metabolism and cellular growth. The activation of AKT leads to enhanced cardiac protection during oxidative stress, endothelial cell injury and cardiac hypertrophy [16]. mTOR, the downstream effector of AKT, has two complexes: raptor-mTOR (TORC1) and rictor-mTOR (TORC2) proteins, which control cell growth and proliferation. Previous studies showed that chronic activation of mTOR led to vascular dysfunction, while its inhibition has been shown to alleviate cardiovascular disorders [14, 17].

The renin-angiotensin system (RAS) is involved in the regulation of blood pressure, inflammation, oxidative stress and the pathogenesis of insu- lin resistance [18]. RAS inhibitors play important roles in prevention of diabetes and vascular diseases. There are two types of the inhibitors: angiotensin-converting enzyme (ACE) inhibitors and angiotensin II receptor blockers (ARBs), which exert various effects on morbidity in hypertensive patients [19]. Captopril was the first identified ACE inhibitor with an antioxidative effect in the treatment of hypertension and heart failure. Recently, it was shown that concomitant administration of captopril can significantly attenuate methotrexate-induced hepatotoxicity in rats due to its antioxidant, anti-inflammatory and anti-apoptotic properties [20]. However, the role of captopril in oxidative stress-induced endothelial cell dysfunction and $\mathrm{H}_{2} \mathrm{O}_{2}$-induced Akt activation remains unclear.

In the present study, a model of oxidative stress was used to investigate the effect of captopril on oxidative stress and cell apoptosis in human coronary artery endothelial cells, and the likely underlying mechanism.

\section{Material amd methods}

\section{Cell culture}

Human coronary artery endothelial cells (HCAECS) were purchased from Cascade Biologics (Portland, OR, USA). The cells were maintained in microvascular endothelium growth medium with endothelial cell growth supplement and 15\% fetal bovine serum at $37^{\circ} \mathrm{C}$ in a humidified atmosphere of $5 \% \mathrm{CO}_{2}$ and $95 \%$ air. Cells (between passages 3 and 6) were grown to $80-90 \%$ confluence, then subjected to serum starvation (0.4\% FBS) for $24 \mathrm{~h}$ and treated with $\mathrm{H}_{2} \mathrm{O}_{2}(500 \mu \mathrm{M})$ [21], captopril $\left(10^{-6} \mathrm{M}\right)$ [22], AKT inhibitor MK-2206 $(250 \mathrm{mmol} / \mathrm{l}$, Cayman Chemical) [23] and the AKT activator SC79 (200 nM, Sigma) [24]. Four groups of cells were used. The HCAECs were pre-treated with captopril alone, or combined with AKT inhibitor or activator, and then exposed to $\mathrm{H}_{2} \mathrm{O}_{2}$ for $48 \mathrm{~h}$. Non-treated HCAECs served as a control group.

\section{Western blot analysis}

Proteins were extracted by placing the HCAECs from each experiment ( $30 \mu \mathrm{g}$ per lane) in lysis buffer, and separated by $10 \%$ or $6 \%$ SDS-PAGE. The separated proteins were transferred to nitrocellulose membranes. After incubation in blocking solution (4\% nonfat milk, Sigma), the membranes were probed overnight with 1 : 2000 dilution primary antibody (monoclonal antibody to p53 (Abcam, USA), ICAM-1 (Abcam, USA), p-Akt (Cell Signaling Technology, USA), p-eNOS (Santa Cruz Biotechnology, USA), p-mTOR (Cell Signaling Technology, USA) and $\beta$-actin (Abcam, USA)). The membranes were washed and then incubated with 
$1: 5000$ dilution of second antibody for $1 \mathrm{~h}$, and the bands were detected with an enhanced chemiluminescence system. Data were normalized to the $\beta$-actin content of the same sample.

\section{Cell viability and apoptosis assays}

Cell viability was assessed by MTT assay, and apoptosis was measured by annexin $\mathrm{V}$ staining. The cells were pre-incubated for $24 \mathrm{~h}$ with captopril $\left(10^{-6} \mathrm{M}\right)$ and then divided into three or four groups which were treated with $\mathrm{H}_{2} \mathrm{O}_{2}(500 \mu \mathrm{M})$ or $\mathrm{H}_{2} \mathrm{O}_{2}(500 \mu \mathrm{M})+$ AKT inhibitor MK-2206 (250 mmol/l, Cayman Chemical) or $\mathrm{H}_{2} \mathrm{O}_{2}(500 \mu \mathrm{M})$ + AKT activator SC79 (200 nM, Sigma), or with captopril $\left(10^{-6} \mathrm{M}\right)$ alone. For the MTT assay, HCAECs were washed with phosphate-buffered saline and then incubated in a fresh medium containing $1 \mathrm{~g} / \mathrm{l}$ MTT (MTT Cell Proliferation Assay Kit, BioVision, Inc.) for $4 \mathrm{~h}$ at $37^{\circ} \mathrm{C}$. After removal of unconverted MTT, absorbance values were measured at $490 \mathrm{~nm}$ in an ELISA reader (Thermo Fisher Scientific, Multiskan). The apoptosis assay was conducted as described previously [25]. Cells were treated with $\mathrm{H}_{2} \mathrm{O}_{2}(500 \mu \mathrm{M})$, captopril $\left(10^{-6} \mathrm{M}\right)$, AKT inhibitor MK-2206 (250 mmol/l) and the AKT activator SC79 (200 nM). The cells were harvested and centrifuged at $500 \times \mathrm{g}$ for $5 \mathrm{~min}$ at $4^{\circ} \mathrm{C}$ and the supernatant was aspirated. The harvested cells were washed with $1 \mathrm{ml}$ of PBS and re-suspended in $100 \mu \mathrm{l}$ of staining buffer (Annexin V-FITC Apoptosis Detection Kit, Sigma Chemical Co, St Louis, MO, USA) by mixing $2 \mu \mathrm{l}$ of Annexin-V and PI. The cells were analyzed with a FlowSight imaging flow cytometer (Amnis, part of EMD Millipore). The $488 \mathrm{~nm}$ laser was used for excitation. Annexin $\mathrm{V}$ positive cells, irrespective of whether they were $\mathrm{PI}$ positive or negative, were considered to be apoptotic in nature, either at the early or late stage of apoptosis.

\section{Measurement of nitrite/nitrate}

Oxidation products of NO (nitrite and nitrate) were assayed as a measure of total NO [26]. The level of NO in the medium of HCAECs was measured using a commercially available nitrite/nitrate assay kit (Nitrate/Nitrite Colorimetric Assay Kit, Cayman Chemicals) according to the manufacturer's instructions. Absorbance values were measured in $550 \mathrm{~nm}$ in an ultraviolet spectrophotometer.

\section{Measurement of ROS generation}

Dichlorofluorescein dye (non-fluorescent CMH2DCFDA) has the ability to diffuse through the cell membrane [27]. The fluorescence intensity is proportional to the ROS content. The levels of ROS in the HCAECS were determined by flow cytometry, using CM-H2DCFDA dye, after incuba- tion with captopril, $\mathrm{H}_{2} \mathrm{O}_{2}$, AKT inhibitor and AKT activator. The cells were trypsinized, washed and re-suspended in $2 \mathrm{ml}$ of HBSS after treatment for $48 \mathrm{~h}$. They were then incubated with $5 \mu \mathrm{M}$ CM-H2DCFDA (prepared in DMSO) for $30 \mathrm{~min}$ at $37^{\circ} \mathrm{C}$ and $5 \% \mathrm{CO}_{2}$. The fluorescence of DCFDA was then measured using a BD FACSCanto Flow cytometer (California, USA). At least 10,000 events were acquired in the gated regions at an emission wavelength of $520 \mathrm{~nm}$.

\section{Proliferation, invasion and migration assays}

\section{BrdU incorporation}

The HCAECs in the different treatments were incubated with $20 \mathrm{mM}$ BrdU (BrdU test kit, Boehringer Mannheim Biochemical) for $2 \mathrm{~h}$ and subsequently fixed and treated with $70 \%$ formamide for $2 \mathrm{~h}$. BrdU was measured by immunocytochemistry.

\section{Wound healing assay}

Fully confluent HCAECs were cultured in 12-well plates. The cells were wounded with a $100 \mu \mathrm{l}$ tip and treated with $0.5 \mathrm{mM} \mathrm{H}_{2} \mathrm{O}_{2}$, captopril $\left(10^{-6} \mathrm{M}\right)$, AKT inhibitor or AKT activator for $48 \mathrm{~h}$. The wound healing assay was conducted in a $\mathrm{CO}_{2}$ incubator. Each scratch was randomly photographed at four separate sites using time-lapse video microscopy (Zeiss Axiovert 135M) with a gas lamina flow attachment at $0 \mathrm{~h}$ and $48 \mathrm{~h}$. The migration rate of HCAECs was determined by the ratio of the wound area at $48 \mathrm{~h}$ to the initial wound area by using Image Pro Plus 6.0 software.

\section{Transwell assay}

The HCAECs $\left(1 \times 10^{6}\right.$ cells $\left./ \mathrm{ml}\right)$ were plated on 12-well Transwell inserts. The volume of medium was $2 \mathrm{ml} /$ well and the volume of each transwell insert was $1 \mathrm{ml}$. The upper chamber $(8-\mu \mathrm{m}$ pores coated with $0.1 \%$ gelatin) containing HCAECs from different treatments was transferred to the bottom chamber containing EBM with $0.2 \%$ FBS and stimulants. After $5 \mathrm{~h}$ of incubation, the non-migrating cells were wiped from the upper side of the membrane. The membrane was fixed and stained using cold methanol. The cell nuclei were stained with $10 \%$ Giemsa and counted under the microscope. The invasion ability was determined by counting the stained cells on the bottom surface.

\section{Statistical analysis}

Data are presented as mean \pm SEM of independent experiments. Statistical analysis was performed using Student's $t$ test for comparison between two groups. The data were analyzed us ing one-way ANOVA, followed by Dunnett multiple 
comparison. Differences were considered significant at $p<0.05$.

\section{Results}

Effect of RAS inhibitor on $\mathrm{H}_{2} \mathrm{O}_{2}$-induced oxidative stress, apoptosis and p-AKT/ mTOR activation in HCAECS

Previous studies showed that endothelial cells exposed to $\mathrm{H}_{2} \mathrm{O}_{2}$ exhibited increased intracellular $\mathrm{O}_{2}^{-}$over basal levels via NOS and NAPDH oxidase pathways [28]. Endothelial cell cytotoxicity and apoptosis were increased with $\mathrm{H}_{2} \mathrm{O}_{2}$ exposure [29]. The results shown in Figures $1 A$ and $D$ indicated that $\mathrm{H}_{2} \mathrm{O}_{2}$ induced cell apoptosis and up-regulated the protein expression of p53 and ICAM-1. It also significantly increased the NO level in HCAECs ( $p<0.05$; Figure $1 \mathrm{~B}$ ). The $\mathrm{H}_{2} \mathrm{O}_{2}$-induced $\mathrm{NO}$ expression and cell apoptosis were significantly reversed by captopril ( $p<0.05$; Figure $1 \mathrm{C}$ ). Cell viability was significantly enhanced by captopril treatment, when compared with the $\mathrm{H}_{2} \mathrm{O}_{2}$ treatment group.

Decreases in eNOS dimer/monomer ratio are indicative of uncoupling of eNOS [30]. Compared with the control group, $\mathrm{H}_{2} \mathrm{O}_{2}$ treatment enhanced eNOS protein expression levels. However, co-treatment with captopril inhibited the $\mathrm{H}_{2} \mathrm{O}_{2}$-induced in eNOS protein expression in HCAECs ( $p<0.05$; Figure $1 \mathrm{D})$.

Intracellular ROS production was assessed by flow cytometry after $\mathrm{H}_{2} \mathrm{O}_{2}$ treatment. Cells co-treated with $\mathrm{H}_{2} \mathrm{O}_{2}$ and captopril showed significant repressed in fluorescence intensity, when compared with cells treated with $\mathrm{H}_{2} \mathrm{O}_{2}$ alone ( $p<$ 0.05 ; Figure $1 \mathrm{E}$ ). There were significant repressed in ROS levels between captopril-treated cells and cells in the control group. These results indicate that captopril has the ability to scavenge ROS, thereby protecting the $\mathrm{HCAECs}$ from $\mathrm{H}_{2} \mathrm{O}_{2}$-induced oxidative stress.

Previous studies showed that the AKT/mTOR pathway is critical for cellular protection against apoptosis [31]. Although the main role of the AKT/ mTOR pathway is regulation of cell growth and survival, AKT activation may also impair cellular function [32]. To assess the effect of captopril on $\mathrm{H}_{2} \mathrm{O}_{2}$-induced $\mathrm{p}$-AKT and mTOR activation, the HCAECs were exposed to $0.5 \mathrm{mM} \mathrm{H}_{2} \mathrm{O}_{2}$ and $10^{-6} \mathrm{M}$ captopril for $48 \mathrm{~h}$, and cell lysates were analyzed by Western blotting. As shown in Figure $1 \mathrm{D}, \mathrm{H}_{2} \mathrm{O}_{2}$ exposure significantly enhanced the protein level of p-AKT and mTOR $(p<0.05)$, while captopril reduced the $\mathrm{H}_{2} \mathrm{O}_{2}$-induced AKT and mTOR phosphorylation. These findings show that captopril blocked the phosphorylation of AKT and mTOR induced by $\mathrm{H}_{2} \mathrm{O}_{2}$.

RAS inhibitor is critical for mitigation of $\mathrm{H}_{2} \mathrm{O}_{2}$-induced oxidative damage via PI3K/AKT/ mTOR pathway.
Co-treatment with captopril and the AKT inhibitor MK-2206 significantly protected HCAECs from $\mathrm{H}_{2} \mathrm{O}_{2}$-induced apoptosis (Figure 2). Cell viability significantly raised after co-exposure to captopril and MK-2206, when compared with the captopril + SC79 group. Furthermore, protein expression levels of P53, ICAM-1 and eNOS were significantly decreased in HCAECs exposed to $\mathrm{H}_{2} \mathrm{O}_{2}$ and captopril + MK-2206 ( $p<0.05$; Figure 3). In contrast, P53 and ICAM-1 expression levels were significantly upregulated in the group treated with $\mathrm{H}_{2} \mathrm{O}_{2}+$ captopril + SC79, relative to the $\mathrm{H}_{2} \mathrm{O}_{2}$ group $(p<0.05)$.

Treatment of HCAECS with captopril + MK-2206 inhibited $\mathrm{H}_{2} \mathrm{O}_{2}$-induced ROS generation and $\mathrm{NO}$ expression ( $p<0.05$; Figure 4$)$. In contrast, ROS generation and $\mathrm{NO}$ expression were significantly increased in HCAECs treated with captopril + SC79 (Figure 5).

Renin-angiotensin system inhibitor blocked $\mathrm{H}_{2} \mathrm{O}_{2}$-induced cell proliferation via the AKT/ mTOR pathway

Cell proliferation can be modulated by changes in intracellular ROS levels [33]. Growth signals and stress responses are known to be largely mediated by the AKT pathway [34]. As shown in Figure 6, captopril and captopril + MK-2206 significantly repressed BrdU labeling when compared with treatment with $\mathrm{H}_{2} \mathrm{O}_{2}$ alone, but in the captopril + SC79 group, the $\mathrm{H}_{2} \mathrm{O}_{2}$-induced cell proliferation was increased $(p<0.05)$. This finding indicates that captopril inhibited the $\mathrm{H}_{2} \mathrm{O}_{2}$-induced cell proliferation via the AKT/mTOR pathway.

\section{RAS inhibitor reversed $\mathrm{H}_{2} \mathrm{O}_{2}$-induced inhibition of cell migration and invasion}

Previous studies reported the role of $\mathrm{H}_{2} \mathrm{O}_{2}$ as a second messenger in the regulation of mammalian cell proliferation and migration [35, 36]. Results from wound healing and transwell assays showed that co-treatment with captopril and the AKT inhibitor MK-2206 alleviated the $\mathrm{H}_{2} \mathrm{O}_{2}$-induced inhibition of HCAEC migration and invasion ( $p<0.05$; Figures 7 and 8). However, there were no effects on migration and invasion when the cells were co-treated with captopril and the AKT activator SC79.

\section{Discussion}

In the present study, the implications of longterm effects of $\mathrm{H}_{2} \mathrm{O}_{2}$-induced oxidative stress on cell viability, apoptosis, eNOS and AKT activation were investigated. The results obtained confirmed that $\mathrm{H}_{2} \mathrm{O}_{2}$ induced cell apoptosis, and increased AKT activation and eNOS expression in HCAECs. These findings are consistent with previous results which showed that $\mathrm{H}_{2} \mathrm{O}_{2}$ increased 


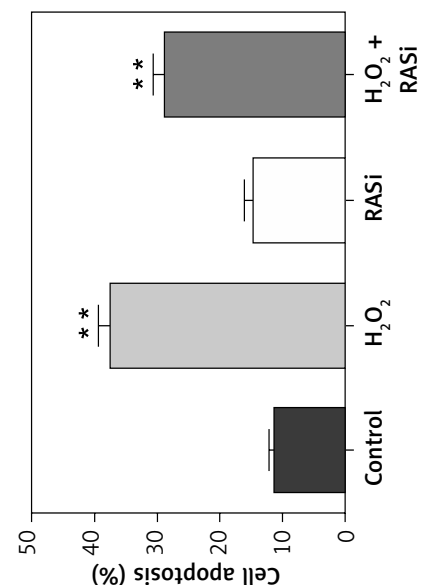

(\%) s!sołdode
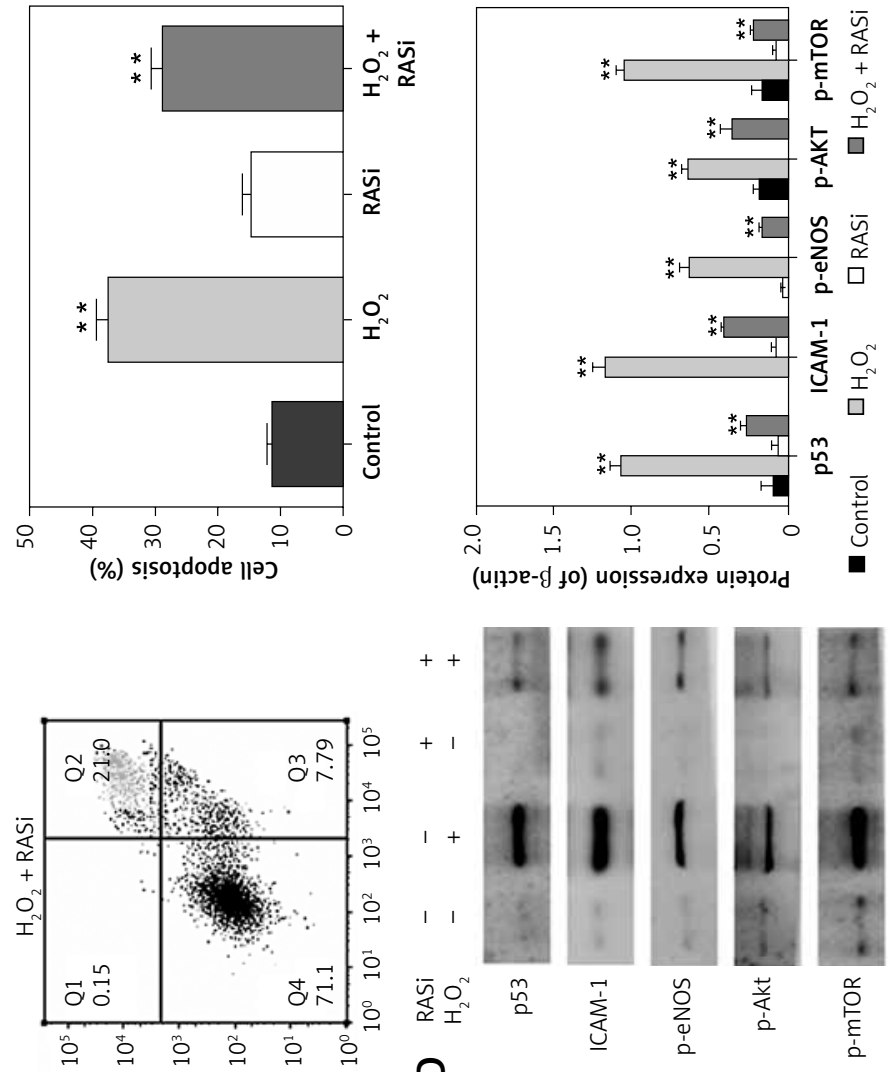

++
+1
$1+$
$1 \quad 1$
$\operatorname{coc}_{0}$
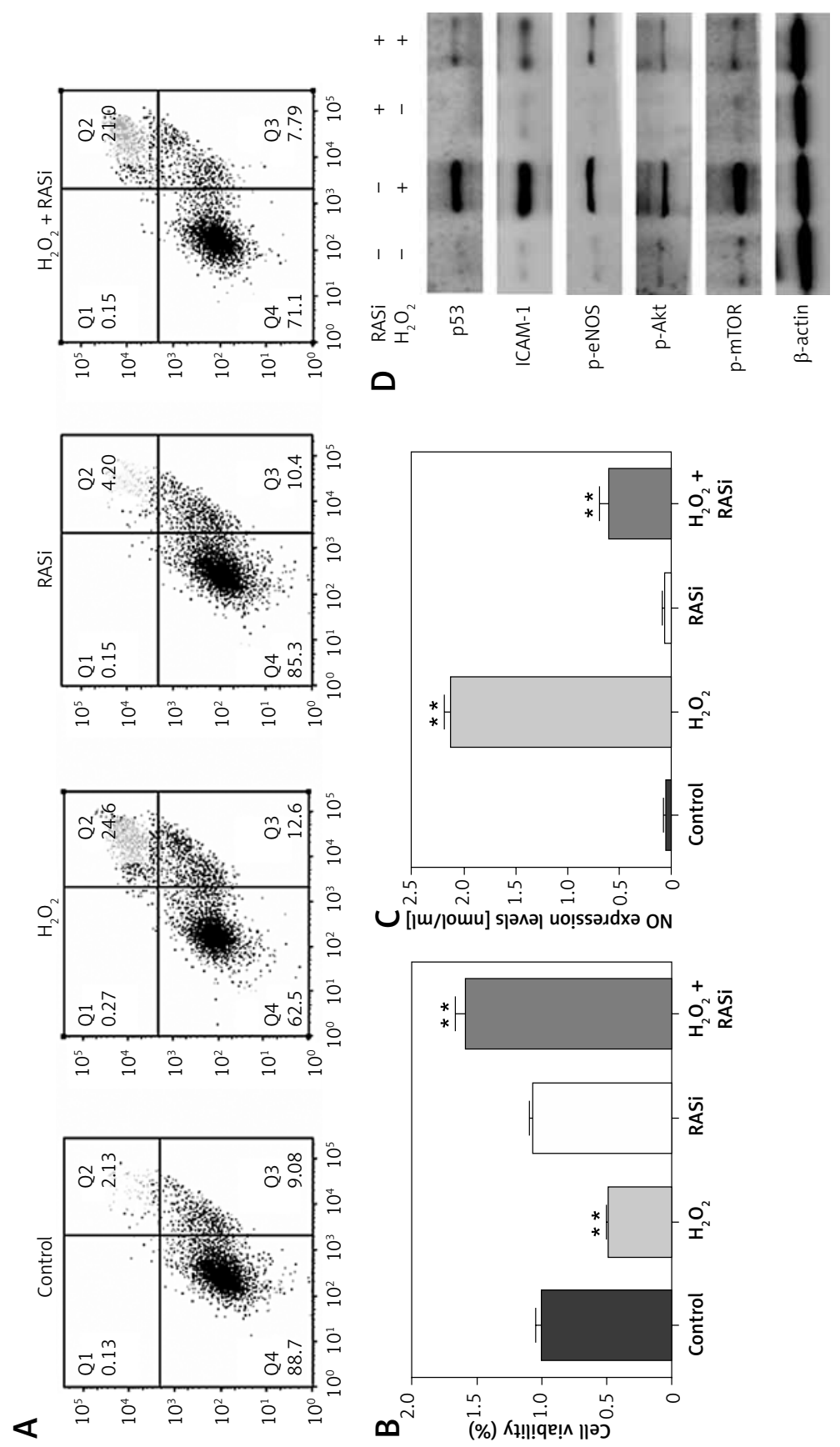

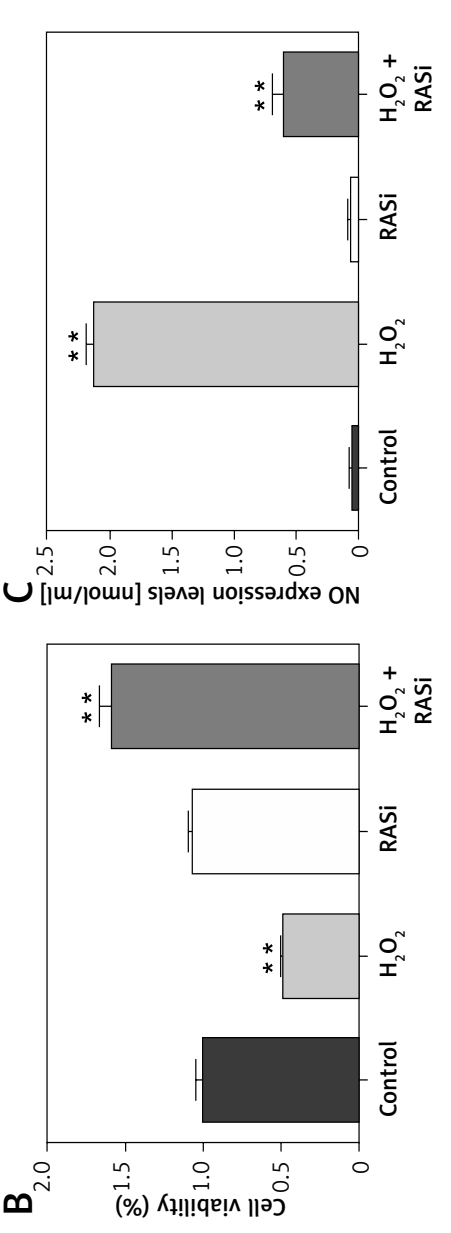

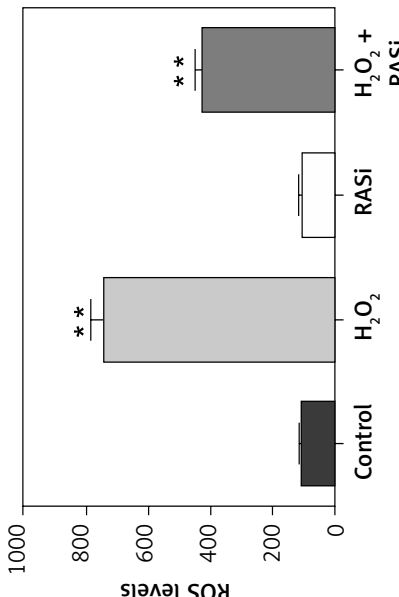

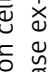

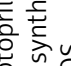

둥을

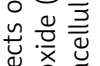

可

$\sum_{i}$

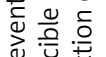

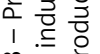

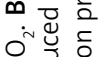

$x^{N} \frac{7}{\square}$ จำ
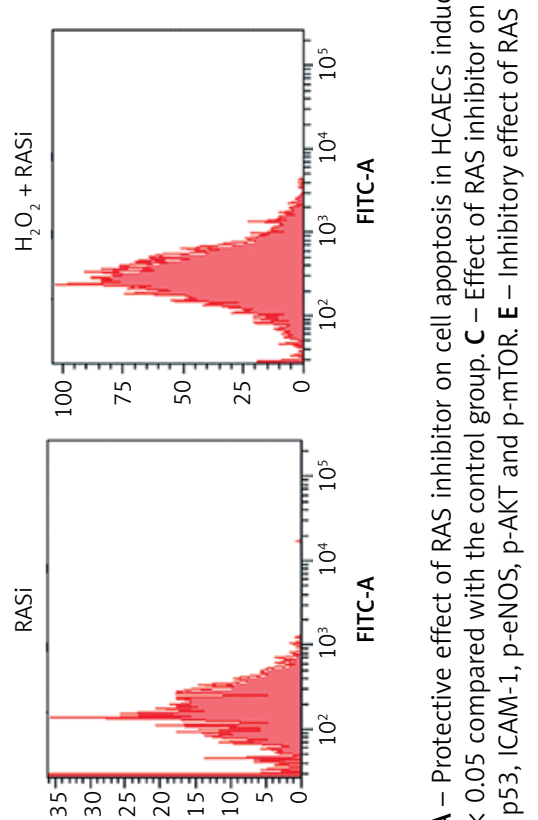

호음

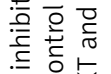

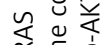
단 记宾论

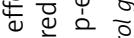

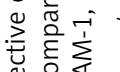

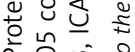

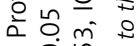
liva

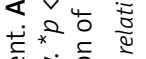
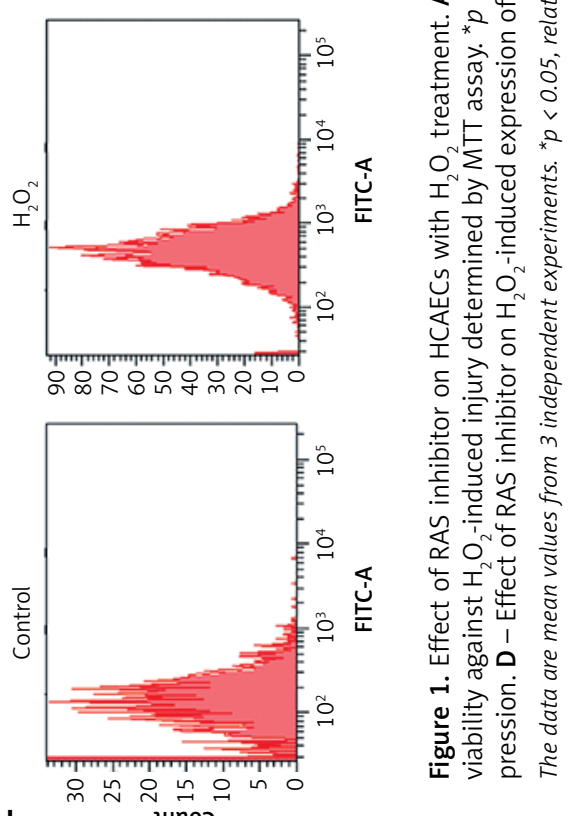

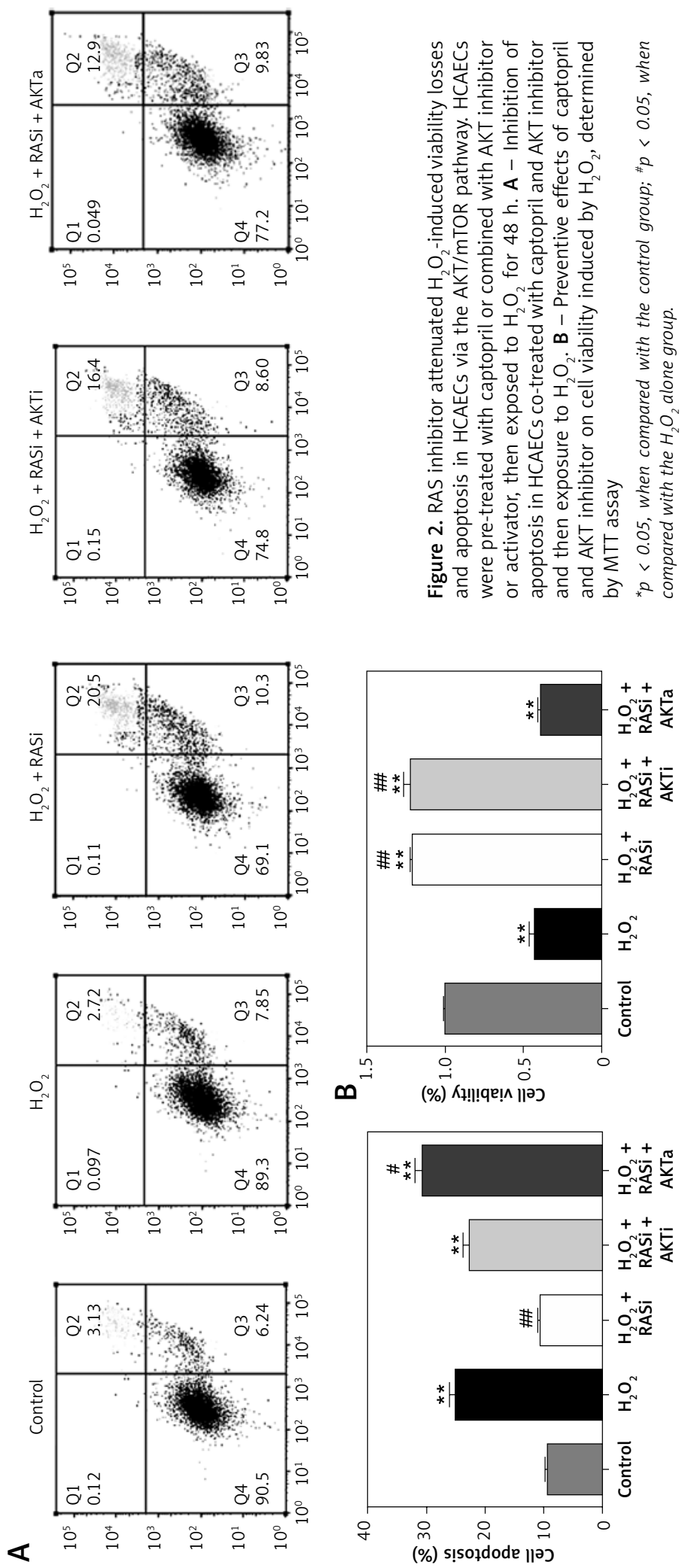

(\%) s!soldode וəכ 
A

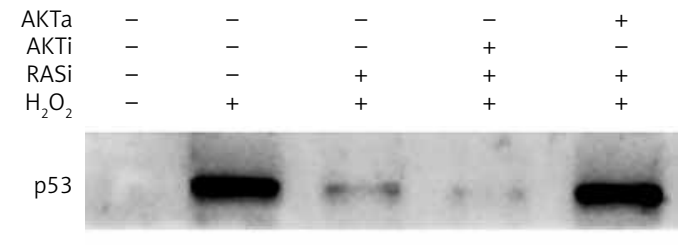

ICAM-1
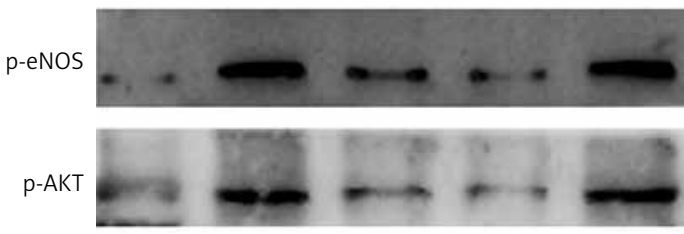

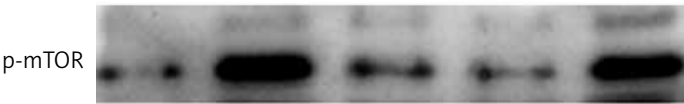

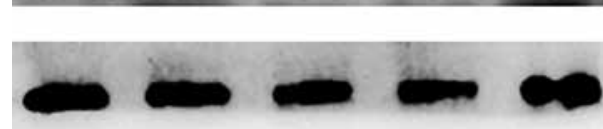

B

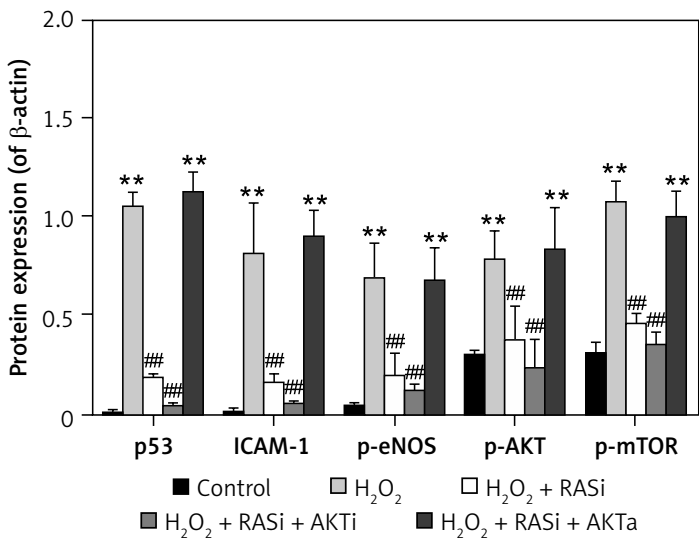

Figure 3. RAS inhibitor attenuated the $\mathrm{H}_{2} \mathrm{O}_{2}$-induced increases in expressions of p53, ICAM-1, p-eNOS, p-AKT and p-mTOR via AKT/mTOR pathway. A - HCAECs were pre-treated with captopril or combined with AKT inhibitor or activator, then exposed to $\mathrm{H}_{2} \mathrm{O}_{2}$ for $48 \mathrm{~h}$. Cell lysate was analyzed for p53, ICAM-1, p-eNOS, p-Akt and p-mTOR protein levels by immunoblotting. B - Shows a column bar graph analysis

${ }^{*} p<0.05$, when compared with the control group; ${ }^{*} p<0.05$, when compared with the $\mathrm{H}_{2} \mathrm{O}_{2}$ alone group.

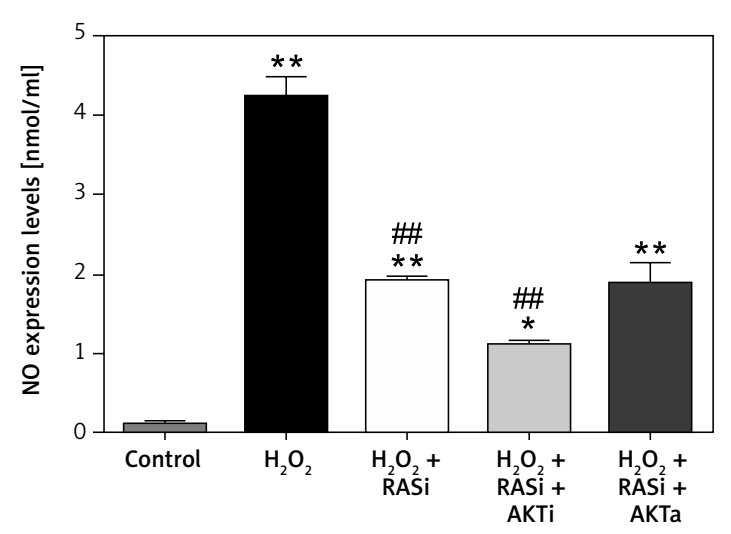

Figure 4. Involvement of the AKT/mTOR signaling pathway in RAS inhibitor-mediated protection against $\mathrm{H}_{2} \mathrm{O}_{2}$-induced inducible nitric oxide (NO) synthase expression. HCAECs were pre-treated with captopril or combined with AKT inhibitor or activator, then exposed to $\mathrm{H}_{2} \mathrm{O}_{2}$ for $48 \mathrm{~h}$. This effect of captopril on $\mathrm{H}_{2} \mathrm{O}_{2}$-induced $\mathrm{NO}$ expression was reversed by AKT activator but not by AKT inhibitor

${ }^{*} p<0.05$, when compared with the control group;

${ }^{\#} p<0.05$, when compared with the $\mathrm{H}_{2} \mathrm{O}_{2}$ alone group.

eNOS expression in $\mathrm{H}_{2} \mathrm{O}_{2}$-treated bovine aortic endothelial cells, and significantly decreased the viability of endothelial cells [37]. The renin-angiotensin system (RAS) is a major physiological system which regulates fluid and electrolyte balance and blood pressure, and it is implicated in the pathogenesis of inflammation, oxidative stress and insulin resistance [38]. Renin-angiotensin system inhibitors improve the NO system and decrease intracellular oxidative stress [39]. Recent studies showed that inhibition of RAS with angiotensin-converting enzyme inhibitors, angiotensin receptor blockers, or a renin inhibitor offers protection from the burden of cardiovascular disease $[40,41]$. The AKT/mTOR pathway has an important role in the cardiovascular system in inhibiting autophagy in cardiomyocytes to prevent cardiac atrophy [42]. On the other hand, recent studies also showed that sustained activity of the Akt/ mTOR pathway induces extensive hypertrophy and cardiac dysfunction [43]. However, the roles of RAS inhibition in oxidative stress-induced endothelial cell dysfunction and $\mathrm{H}_{2} \mathrm{O}_{2}$-induced AKT activation remained uninvestigated.

Captopril, an RAS inhibitor, has been used for more than a decade to treat high blood pressure and reduce mortality and cardiovascular injury among patients with myocardial infarction complicated by ventricular systolic dysfunction and heart failure [44, 45]. Oxidative stress is also considered to play an important role in the pathogenesis of both types of diabetes [46] and cardiovascular disease. In the present study, 

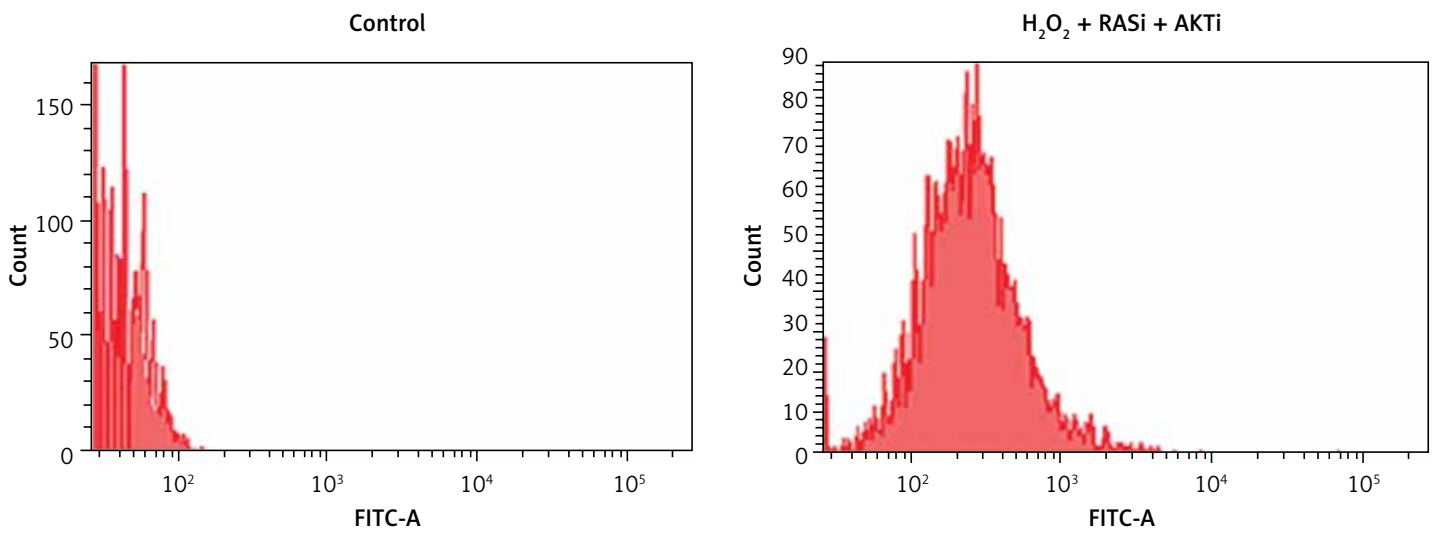

$\mathrm{H}_{2} \mathrm{O}_{2}$
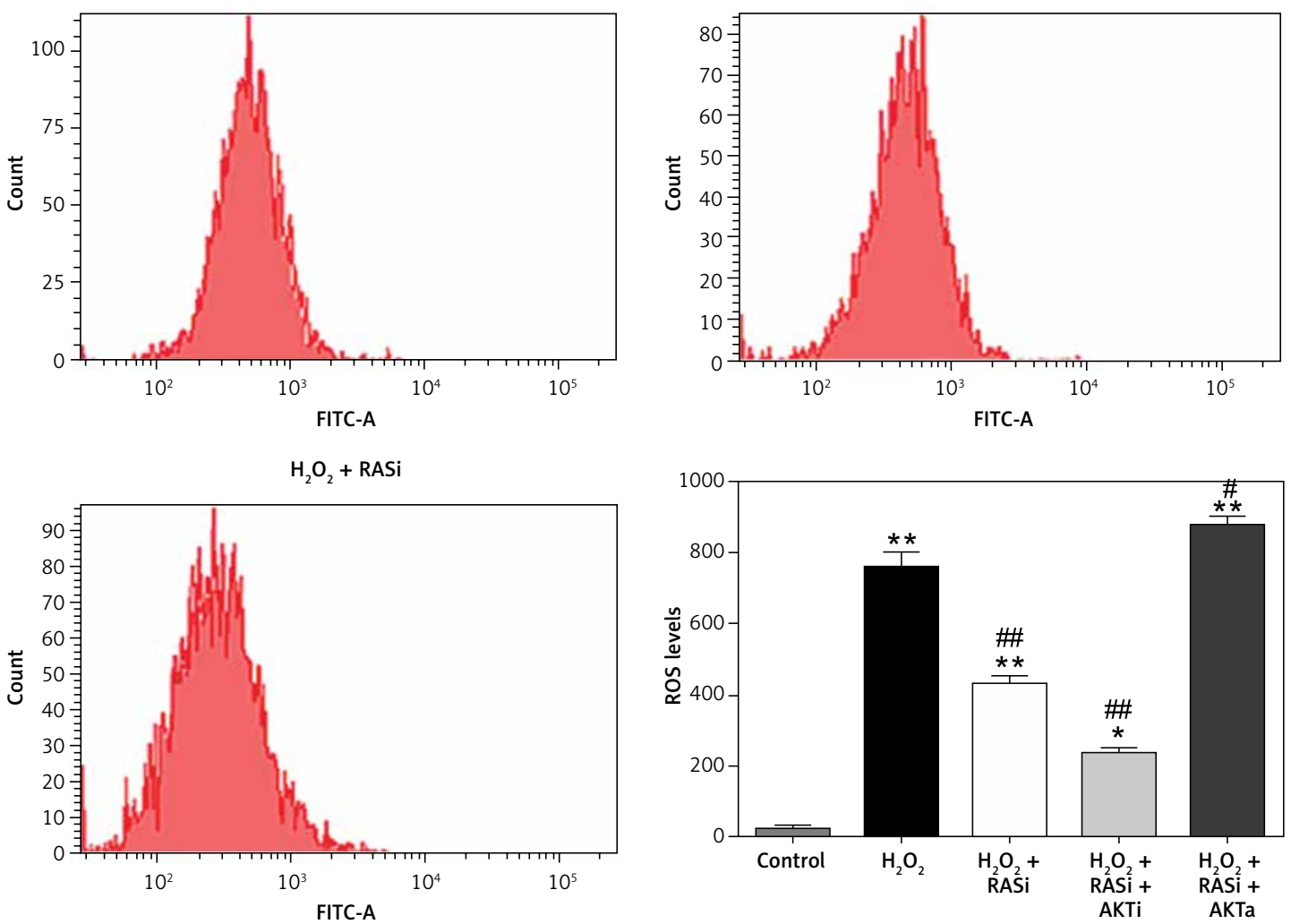

Figure 5. Involvement of the AKT/mTOR signaling pathway in inhibitory effect of RAS inhibitor on production of intracellular ROS. The intracellular ROS accumulation was determined by measuring the DCF-derived fluorescence after incubation of cells with DCFH-DA for $30 \mathrm{~min}$. The data are mean values from 3 independent experiments

${ }^{*} p<0.05$, when compared with the control group; ${ }^{*} p<0.05$, when compared with the $\mathrm{H}_{2} \mathrm{O}_{2}$ alone group.

a $\mathrm{H}_{2} \mathrm{O}_{2}$-induced oxidative stress model was used to mimic the characteristic pathologies of cardiovascular disease in vivo, so as to study the protective effects of captopril and its probable mechanisms of action. It has been shown that excess ROS production can cause oxidative damage to DNA, thereby triggering genomic instability and cell death [47].

The effect of captopril on the viability and migration of HCAECs exposed to $\mathrm{H}_{2} \mathrm{O}_{2}$ was investigated in this study by wound healing and MTT assays. Apoptosis was also assessed by annexin
V-binding and p53 expression. It was found that captopril protected HCAECs from $\mathrm{H}_{2} \mathrm{O}_{2}$-induced oxidative cell damage and inhibition of cell migration. It was also found that captopril and the AKT inhibitor MK-2206 significantly protected HCAECs from $\mathrm{H}_{2} \mathrm{O}_{2}$-induced apoptosis. Although AKT plays a critical role in regulating the lifespan of primary cultured human cells [48], a previous study showed that constitutive activation of AKT may induce endothelial cell senescence in atheroma tissue, thereby contributing to atherogenesis [49]. In the present study, AKT activation was in- 

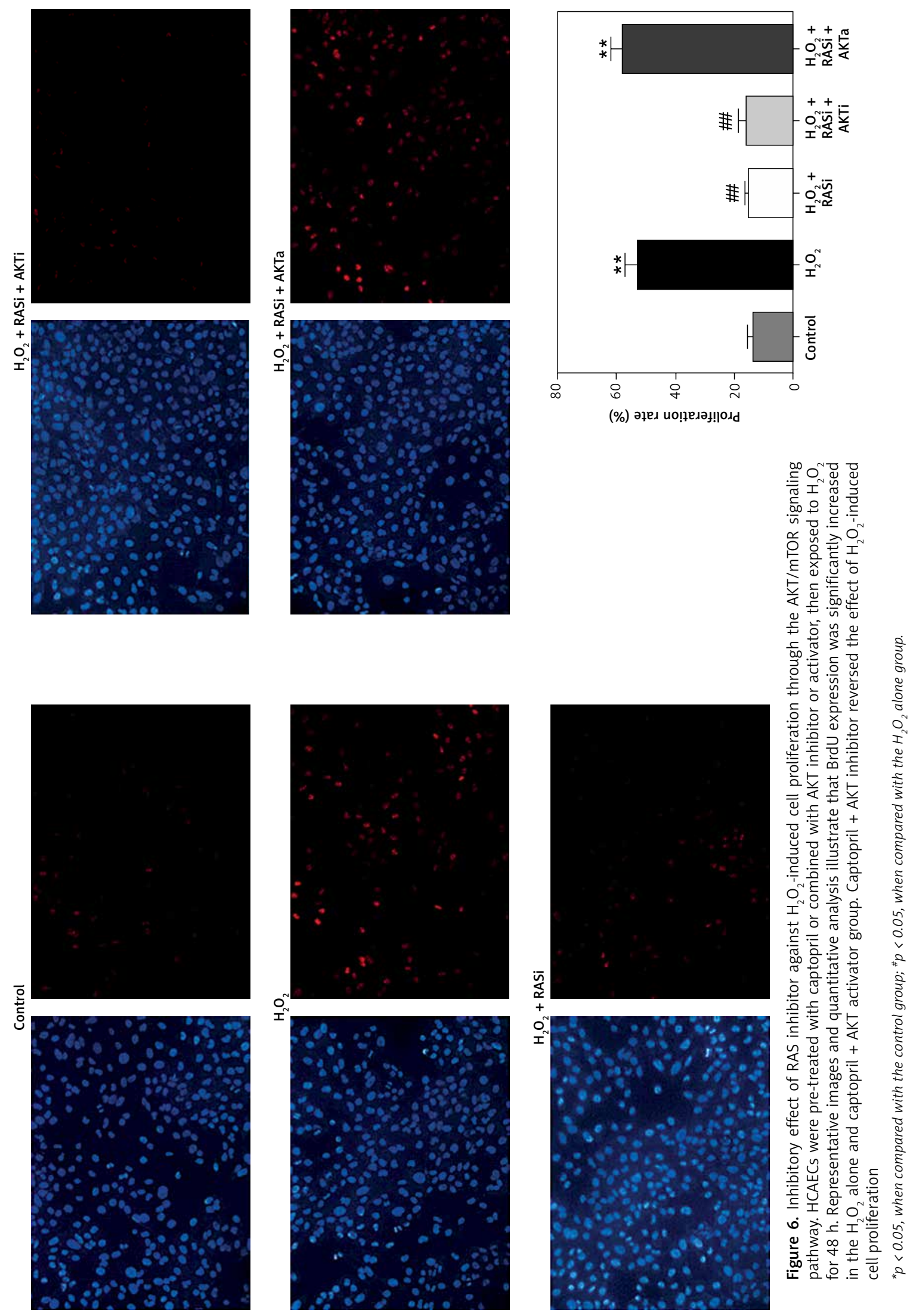

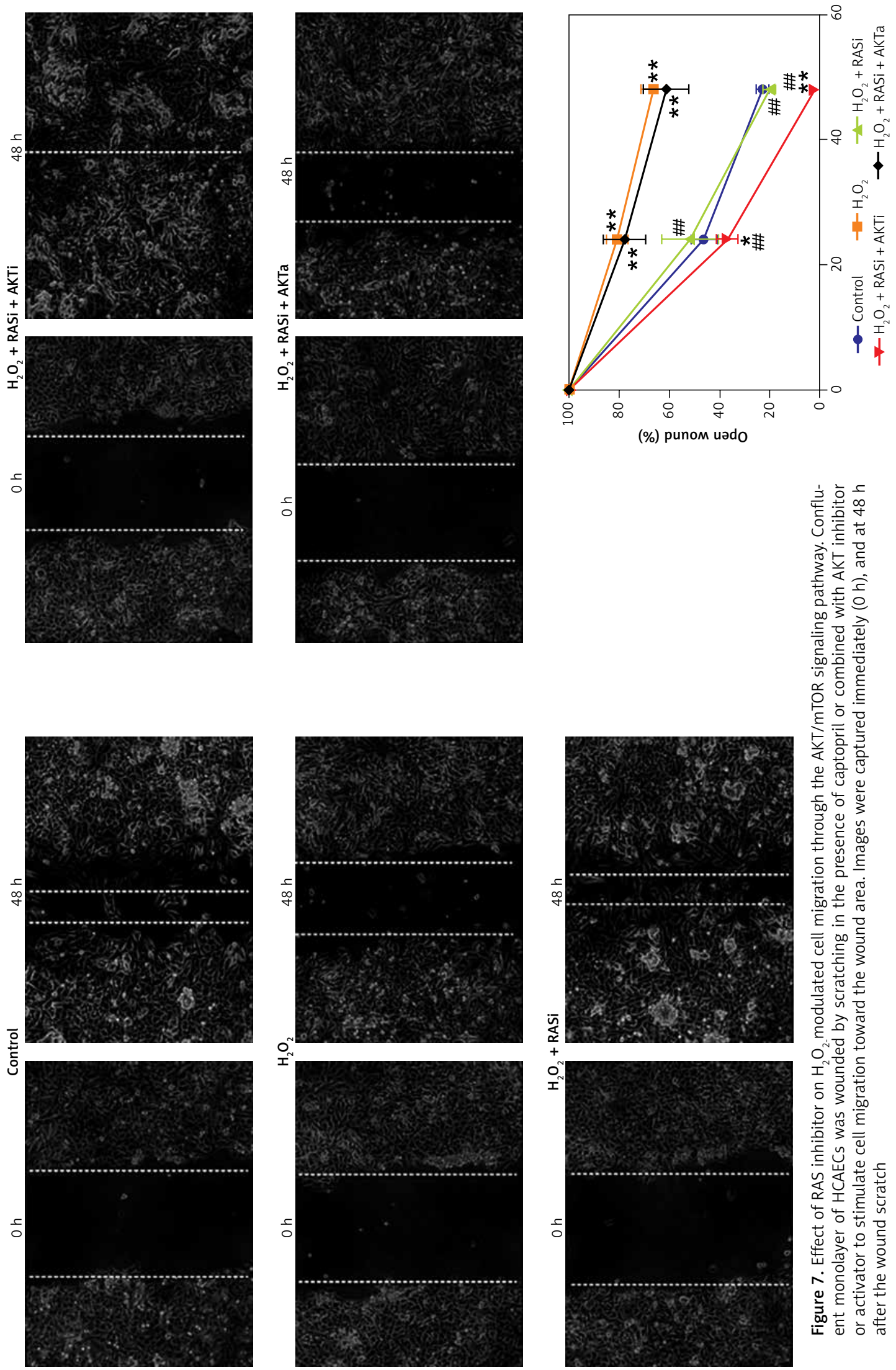

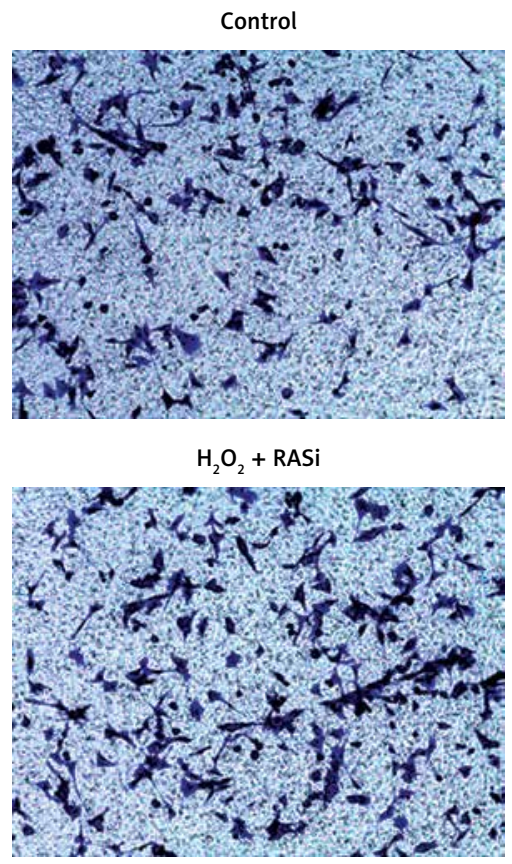

$\mathrm{H}_{2} \mathrm{O}_{2}+\mathrm{RASi}+\mathrm{AKTa}$

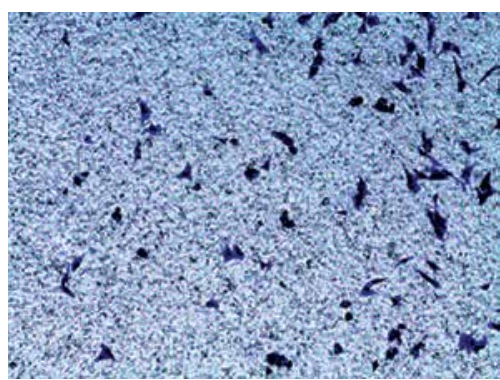

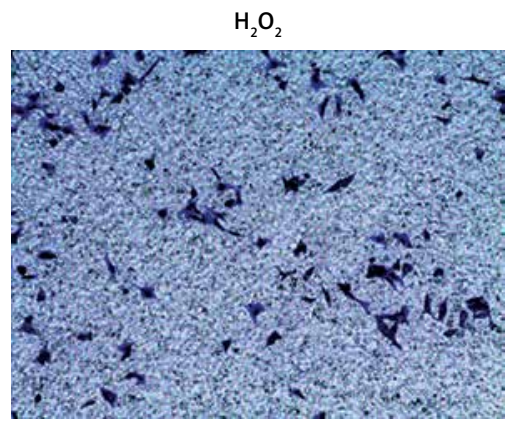

$\mathrm{H}_{2} \mathrm{O}_{2}+\mathrm{RASi}+\mathrm{AKTi}$
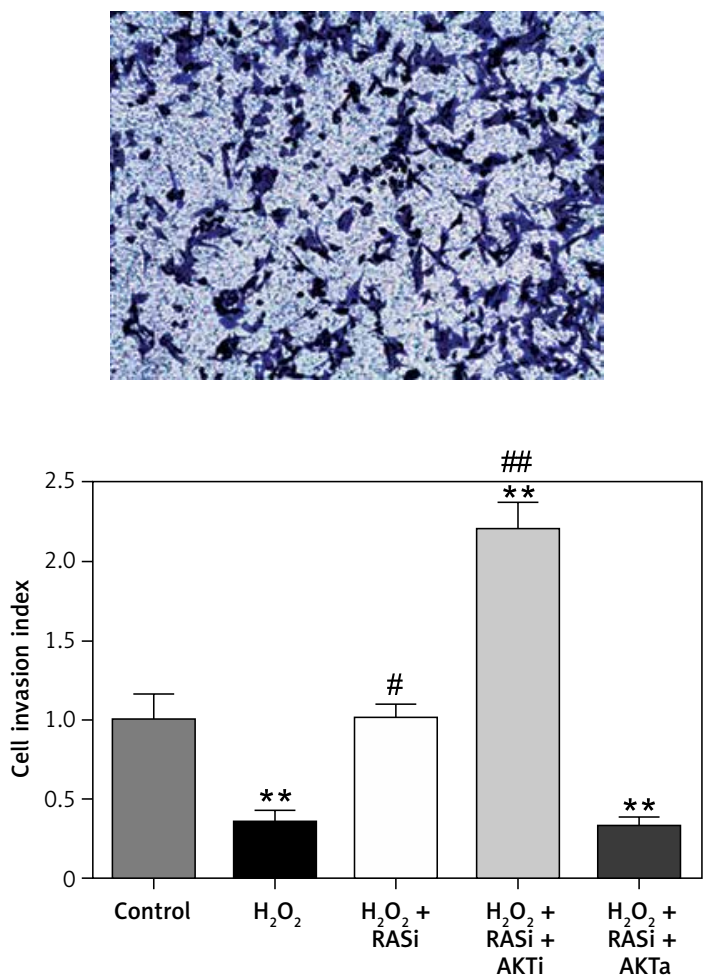

Figure 8. RAS inhibitor reduced $\mathrm{H}_{2} \mathrm{O}_{2}$-induced inhibition of HCAEC motility in a transwell migration assay via the AKT/mTOR signaling pathway. HCAEC migration rate was examined after $\mathrm{H}_{2} \mathrm{O}_{2}$ stimulation with or without AKT inhibitor or activator. Captopril alone or in co-treatment with AKT inhibitor increased the rate of HCAEC migration ${ }^{*} p<0.05$, when compared with the control group; ${ }^{*} p<0.05$, when compared with the $\mathrm{H}_{2} \mathrm{O}_{2}$ alone group.

duced by $\mathrm{H}_{2} \mathrm{O}_{2}$, and co-treatment with captopril reversed this effect. However, there were no additional effect of the AKT inhibitor compared with captopril alone. Captopril markedly decreased the phosphorylation of AKT. The AKT signaling pathways are important signaling cascades downstream of ROS. These findings are consistent with previous results which showed that chronic activation of the AKT/mTOR signaling pathway leads to oxidative stress induced apoptosis [50].

The AKT/mTOR signaling pathway is involved in cell migration and invasion [51]. Previous studies showed that the AKT/mTOR pathway could regulate cellular oxidative stress and was involved in mediating vascular dysfunction [52]. Our results are consistent with previously published studies. The results of the present study demonstrated that $\mathrm{H}_{2} \mathrm{O}_{2}$ promoted the activation of AKT and inhibited cell migration and invasion, but these effects were suppressed by co-treatment with captopril and the AKT inhibitor MK-2206.

In conclusion, the novel finding in this study is that the protective effect of captopril against $\mathrm{H}_{2} \mathrm{O}_{2}$-induced apoptosis occurs through the AKT/ mTOR pathway and contributes to enhanced cell survival. This association between $\mathrm{H}_{2} \mathrm{O}_{2}$-induced AKT activation and RAS inhibitors, and suppression of oxidative stress-induced apoptosis, has not been reported previously. These findings provide new insight into the protective effects of captopril 
and novel therapeutic approaches for regulating cell survival and cell death due to disorders such as cellular dysfunction and dysregulation of intracellular oxidative stress.

\section{Conflict of interest}

The authors declare no competing interest.

\section{References}

1. Makarenko VV, Usatyuk PV, Yuan G, et al. Intermittent hypoxia-induced endothelial barrier dysfunction requires ROS-dependent MAP kinase activation. Am J Physiol Cell Physiol 2014; 306: C745-52.

2. Sena CM, Pereira AM, Seiça R. Endothelial dysfunction a major mediator of diabetic vascular disease. Biochim Biophys Acta 2013; 1832: 2216-31.

3. Ross R. Atherosclerosis - an inflammatory disease. N Engl J Med 1999; 340: 115-26.

4. Ellidag HY, Aydin O, Eren E, et al. Phenotype distribution of the paraoxonase gene in patients with cardiac disease. Arch Med Sci 2017; 13: 820-6.

5. Gimbrone MA. Vascular endothelium: an integrator of pathophysiologic stimuli in atherosclerosis. Am J Cardiol 1995; 75: 67B-70B.

6. Förstermann U. Nitric oxide and oxidative stress in vascular disease. Pflügers Archiv 2010; 459: 923-39.

7. Förstermann U, Nakane M, Tracey WR, Pollock JS. Isoforms of nitric oxide synthase: functions in the cardiovascular system. Eur Heart J 1993; 14: 10-5.

8. Li H, Junk P, Huwiler A, et al. Dual effect of ceramide on human endothelial cells. Circulation 2002; 106: 2250-6.

9. Ding Y, Gao BB, Zhou L, et al. Clinical implications of plasma Nogo-A levels in patients with coronary heart disease. Arch Med Sci 2017; 13: 771-7.

10. Wang SL, Liu DS, Liang ES, et al. Protective effect of allicin on high glucose/hypoxia-induced aortic endothelial cells via reduction of oxidative stress. Exp Therap Med 2015; 10: 1394-400.

11. Rhee SG, Chang TS, Bae YS, Lee SR, Kang SW. Cellular regulation by hydrogen peroxide. J Am Soc Nephrol 2003; 14 (8 Suppl 3): S211-5.

12. Higashi Y, Noma K, Yoshizumi M, Kihara Y. Endothelial function and oxidative stress in cardiovascular diseases. Circ J 2009; 73: 411-8.

13. Cadenas E, Davies KJ. Mitochondrial free radical generation, oxidative stress, and aging. Free Radic Biol Med 2000; 29: 222-30.

14. Rhee SG, Bae YS, Lee SR, Kwon J. Hydrogen peroxide: a key messenger that modulates protein phosphorylation through cysteine oxidation. Sci STKE 2000; 2000: pe1.

15. Fruehauf JP, Meyskens FL. Reactive oxygen species: a breath of life or death? Clin Cancer Res 2007; 13: 789-94.

16. Maiese K, Chong ZZ, Hou J, Shang YC. Oxidative stress: biomarkers and novel therapeutic pathways. Exp Gerontol 2010; 45: 217-34.

17. Mancini D, Pinney S, Burkhoff D, et al. Use of rapamycin slows progression of cardiac transplantation vasculopathy. Circulation 2003; 108: 48-53.

18. Kalupahana N, Moustaid-Moussa N. The renin-angiotensin system: a link between obesity, inflammation and insulin resistance. Obes Rev 2012; 13: 136-49.

19. Danchin N, Cucherat M, Thuillez C, Durand E, Kadri Z, Steg PG. Angiotensin-converting enzyme inhibitors in patients with coronary artery disease and absence of heart failure or left ventricular systolic dysfunction: an overview of long-term randomized controlled trials. Arch Intern Med 2006; 166: 787-96.

20. Kelleni MT, Ibrahim SA, Abdelrahman AM. Effect of captopril and telmisartan on methotrexate-induced hepatotoxicity in rats: impact of oxidative stress, inflammation and apoptosis. Toxicol Mech Methods 2016; 26: 371-7.

21. Stone JR, Collins T. The role of hydrogen peroxide in endothelial proliferative responses. Endothelium 2002; 9: 231-8.

22. Rump A, Klaus W. Evidence for norepinephrine cardiotoxicity mediated by superoxide anion radicals in isolated rabbit hearts. Naunyn-Schmiedeberg's Arch Pharmacol 1994; 349: 295-300.

23. Petrich AM, Leshchenko V, Kuo PY, et al. Akt inhibitors MK-2206 and nelfinavir overcome mTOR inhibitor resistance in diffuse large B-cell lymphoma. Clin Cancer Res 2012; 18: 2534-44.

24. Ribeiro DL, Pinto ME, Maeda SY, Taboga SR, Góes RM. High fat-induced obesity associated with insulin-resistance increases FGF- 2 content and causes stromal hyperplasia in rat ventral prostate. Cell Tissue Res 2012; 349: $577-88$

25. Aubry JP, Blaecke A, Lecoanet-Henchoz S, et al. Annexin $\checkmark$ used for measuring apoptosis in the early events of cellular cytotoxicity. Cytometry 1999; 37: 197-204.

26. Moshage H, Kok B, Huizenga JR, Jansen P. Nitrite and nitrate determinations in plasma: a critical evaluation. Clin Chem 1995; 41: 892-6.

27. Eruslanov E, Kusmartsev S. Identification of ROS using oxidized DCFDA and flow-cytometry. Methods Mol Biol 2010; 564: 57-72.

28. Coyle CH, Martinez LJ, Coleman MC, Spitz DR, Weintraub NL, Kader KN. Mechanisms of H2O2-induced oxidative stress in endothelial cells. Free Radic Biol Med 2006; 40: 2206-13.

29. Luo T, Xia Z. A small dose of hydrogen peroxide enhances tumor necrosis factor-alpha toxicity in inducing human vascular endothelial cell apoptosis: reversal with propofol. Anesth Analg 2006; 103: 110-6.

30. Roe ND, Ren J. Nitric oxide synthase uncoupling: a therapeutic target in cardiovascular diseases. Vasc Pharmacol 2012; 57: 168-72.

31. Cantley LC. The phosphoinositide 3-kinase pathway. Science 2002; 296: 1655-7.

32. Hua Y, Zhang Y, Ceylan-Isik AF, Wold LE, Nunn JM, Ren J. Chronic Akt activation accentuates aging-induced cardiac hypertrophy and myocardial contractile dysfunction: role of autophagy. Basic Res Cardiol 2011; 106: 1173-91.

33. Sauer H, Wartenberg M, Hescheler J. Reactive oxygen species as intracellular messengers during cell growth and differentiation. Cell Physiol Biochem 2001; 11: 173-86.

34. Zoncu R, Sabatini DM, Efeyan A. mTOR: from growth signal integration to cancer, diabetes and ageing. Nature Rev Mol Cell Biol 2011; 12: 21-35.

35. Trachootham D, Lu W, Ogasawara MA, Valle NR, Huang P. Redox regulation of cell survival. Antioxid Redox Signaling 2008; 10: 1343-74.

36. Rhee SG. H2O2, a necessary evil for cell signaling. Science 2006; 312: 1882-3.

37. Wang YK, Hong YJ, Wei M, et al. Curculigoside attenuates human umbilical vein endothelial cell injury induced by H2O2. J Ethnopharmacol 2010; 132: 233-9.

38. Husain K, Hernandez W, Ansari RA, Ferder L. Inflammation, oxidative stress and renin angiotensin system in atherosclerosis. World J Biol Chem 2015; 6: 209-17. 
39. Fujii H, Kono K, Nakai K, et al. Renin-angiotensin system inhibitors reduce serum asymmetric dimethylarginine levels and oxidative stress in normotensive patients with chronic kidney disease. Nephron Extra 2014; 4: 18-25.

40. Ismail H, Mitchell R, McFarlane SI, Makaryus AN. Pleiotropic effects of inhibitors of the RAAS in the diabetic population: above and beyond blood pressure lowering Curr Diab Rep 2010; 10: 32-6.

41. Yong QC, Thomas CM, Seqqat R, Chandel N, Baker KM, Kumar R. Angiotensin type $1 \mathrm{a}$ receptor-deficient mice develop diabetes-induced cardiac dysfunction, which is prevented by renin-angiotensin system inhibitors. Cardiovasc Diabetol 2013; 12: 169.

42. Wullschleger $S$, Loewith R, Hall MN. TOR signaling in growth and metabolism. Cell 2006; 124: 471-84.

43. Shiojima I, Sato K, Izumiya Y, et al. Disruption of coordinated cardiac hypertrophy and angiogenesis contributes to the transition to heart failure. J Clin Investig 2005; 115: 2108-18.

44. Snauwaert E, Walle JV, De Bruyne P. Therapeutic efficacy and safety of ACE inhibitors in the hypertensive paediatric population: a review. Arch Dis Child 2017; 102: 63-71.

45. Susalit E, Agus N, Effendi I, et al. Olive (Olea europaea) leaf extract effective in patients with stage- 1 hypertension: comparison with captopril. Phytomedicine 2011; 18: 251-8.

46. Tian M, Qing C, Niu Y, et al. Aminoguanidine cream ameliorates skin tissue microenvironment in diabetic rats. Arch Med Sci 2016; 12: 179-87.

47. Reuter S, Gupta SC, Chaturvedi MM, Aggarwal BB. Oxidative stress, inflammation, and cancer: how are they linked? Free Radic Biol Med 2010; 49: 1603-16.

48. Zhang X, Tang N, Hadden TJ, Rishi AK. Akt, FoxO and regulation of apoptosis. Biochim Biophys Acta 2011; 1813: 1978-86.

49. Minamino T, Miyauchi H, Tateno K, Kunieda T, Komuro I. Akt-induced cellular senescence: implication for human disease. Cell Cycle 2004; 3: 447-9.

50. van Gorp AG, Pomeranz KM, Birkenkamp KU, Hui RC, Lam EW, Coffer PJ. Chronic protein kinase B (PKB/Cakt) activation leads to apoptosis induced by oxidative stress-mediated Foxo3a transcriptional up-regulation. Cancer Res 2006; 66: 10760-9.

51. Zhang J, Wang X, Vikash V, et al. ROS and ROS-mediated cellular signaling. Oxid Med Cellular Longev 2016; 2016: 4350965.

52. Nishi J, Minamino T, Miyauchi H, et al. Vascular endothelial growth factor receptor-1 regulates postnatal angiogenesis through inhibition of the excessive activation of Akt. Circ Res 2008; 103: 261-8. 